from the Carboniferous rocks of Midlothian, which has been filled in with volcanic débris, but still has some of the woody structures most beautifully preserved; a unique example of the antler of Cervus verticornis, from the Norfolk Forest Bed; the wonderful horned and other reptiles from the Elgin sandstone; the elephant remains described by Dr. Hicks from near Euston Square, and lastly, the fossil human remains from Galley Hill, Northfleet; probably the best authenticated specimen of Palæolithic man yet found.

The President then gave a brief account of the arrangements of specimens in the Rock-room (see ProceEdings, vol. xii, p. 322, and vol. xiv, p. 97), and concluded by expressing the thanks of the Association to Mr. Rudler and Mr. E. T. Newton for their excellent addresses.

\title{
VISIT TO THE SOUTH KENSINGTON MUSEUM, SCIENCE DIVISION.
}

Saturday, March $26 \mathrm{Th}$, i 898.

Director: Profesșor J. IV. Judd, C.B., LL.D., F.R.S.

(Report by H. W. MONCKTON, with corrections and additions by the DrRECTOR.)

THE members of the Association were received by the Director in the vestibule of the western galleries at 3 p.m. After a few words of welcome, the Director led the way into the gallery, drawing attention, at the entrance, to some old maps of London which illustrate the gradual growth of our city, and show how much the direction of its extension has been influenced by geological features. It would be impossible within the confines of this report even to mention the numerous objects of interest having a bearing on geology to which the Director drew attention, nor is it necessary to do so, for the gallery is open to the public and the exhibits are most carefully and clearly labelled; but a few may be mentioned as having more particularly attracted the attention of the members of the party.

General Colby's "compensation bar," a most ingenious arrangement of brass and iron, was used in $1827-8$ in the measurement of base lines on Salisbury Plain and near Lough Foyle, for the Ordnance Survey of the British Isles, and is of interest to the geologist since the value of a geological map depends to no inconsiderable extent on the perfection of the topographical survey of the area in question. The zenith-sector, and the great theodolite used in the Ordnance Survey attracted attention, as did also the very compact piece of apparatus used by Prof. Boys in determining the constant of gravitation, and thus weighing the earth.

JULY, I 898.$]$ 
The Director then drew attention to a beautiful series of sketches in chalk of the wonderful sunset effects which followed the great eruption of Krakatoa in August, I883, supposed to have been due to the vast quantities of excessively fine volcanic dust thrown into the air during the eruption. These drawings were all made in the neighbourhood of London, by Mr. W. Ascroft. They are mounted on revolving frames, and some time was spent in their inspection by the members.

On entering the second gallery the course of the tour of inspection was interrupted by a small geyser which suddenly came very actively into operation. During one of its passive periods the Director explained its construction, which is beautifully simple, simpler even than the model designed by Prof. J. Müller, of Freiburg, which required two fires, whereas the one inspected needed only one. The Director said that the violence of the eruption could be greatly increased by a diminution in the aperture of the tube, but there was a general feeling that the eruption was sufficiently formidable. A beautiful working apparatus, constructed by $\mathrm{Mr}$. Clayden, showed the ocean currents of the world, and the effect on the Gulf Stream of the removal of Central America was illustrated. Another working model, designed by Mr. C. J. Woodward, of Birmingham, illustrated the formation and manner of growth of a volcanic cone in a simple and ingenious manner.

A large number of pieces of apparatus made expressly for geoogical or mineralogical investigation were shown, and examined with critical interest by members whose tastes lay in various special directions. Specific-gravity balances had a fascination for some; petrological microscopes and machines for cutting rocksections for others, and several beautiful series of models to illustrate the principles of crystallography attracted the attention of all.

A very instructive series of geological maps, containing representative examples of the publications of the various European, American, and Colonial Geological-Surveys with early geological maps of historical interest, and some geological models, next engaged the attention of the members. After an inspection, all too hurried, of these and many other exhibits, the party passed on to a lecture-room, where Professor Iudd gave a short address on

\section{Geological Maps: Their Origin and Development.}

The collection of geological maps exhibited in the galleries of the Museum enables the geologist to contrast the various excellences and defects which such maps may display. Some of these maps are distinguished by the fidelity with which they illustrate the geological structure of a district; others are noteworthy for the beauty, transparency, and harmony of their colouring, being truly artistic as well as scientific productions; while others again, 
and this is a matter of no little importance, are remarkable for the methods of reproduction adopted, which enable them to be sold at an extremely cheap rate.

It is of great interest to the geologist to study the various steps by which the art of geological mapping has arrived at its present state of development. For this reason a historical series of geological maps has been arranged in the galleries. The whole question of the origin of geological maps has been treated with great learning and research by Dr. W. H. Fitton, in an article first published in the Edinburgh Revieze in 1818 , and afterwards issued in more extended form in the Philosophical Magazine for 1832-3. Although some of Dr. Fitton's conclusions have been challenged by more recent authors, a careful study of the facts affords the strongest proof of the sound judgment and perfect impartiality of that distinguished geologist.

In the history of scientific discovery, much more importance attaches to those enunciations of truth which have been placed before the world in such a way as to influence scientific progress and produce real results, than to the remarkable (but often dim) foreshadowings of the same truth that may have preceded the effective discovery by some years, but have borne no iruit whatever.

Three very distinct stages in the development of the art of geological mapping may be very clearly recognised, and these will always be associated with the names of Lister, Werner, and Smith respectively.

The first maps of the kind could not be called "geological" maps at all in the proper sense of the term-they were simply mineral or agricultural (soil) maps. It is impossible to say when such maps were first constructed. To many persons, in distant places, it must have occurred to indicate upon the surface of a map, the distribution of minerals and soils. To construct such a map, indeed, would require nothing but the most ordinary industry and perseverance. But there can be no doubt that a paper by the "learned Dr. Martin Lister," published in the Philosophical Transactions for I684, had a most important influence in pointing out the value and uses of such maps, and in quickening research in that direction.

Maps which could be properly called "geological" were first produced when the fact came to be clearly recognised that the rocks seen at the surface are the "basset edges" or "outcrops" of strata, and that these strata have an invariable order of succession. Now although Werner was anticipated in this discovery by Steno in Italy (1669), by Strachey (1719-1725) and Michell (1760) in this country, and by Lehmann (1756) and Fuchsel $(1762)$ in Germany, yet it is certainly due to the efforts of the great Saxon mineralogist, at the end of the last century, that geological maps began to be extensively made. Werner's pupils, fired with his enthusiasm and informed with his exact mineralogical 
knowledge, went all over the world seeking to apply the principles of their master, and like him endeavouring to represent the structure of the countries they visited upon the surface of maps.

The third stage in the evolution of the geological map followed at the commencement of the present century, on the discovery by William Smith, that strata can be identified by their organic remains. It was this notable discovery which rescued geological cartography from the confusion into which it was falling, by the too rigid adherence of the disciples of Werner to the just but narrow teachings of their great master. It has been pointed out by M. Jules Marcou that Smith's great discovery had been adumbrated by the Abbé Giraud-Soulavie, as early as 1777. But the work of Giraud-Soulavie was absolutely unknown to William Smith, and even to Cuvier and Brongniart, who first applied the principles of William Smith to the investigation of the Paris Basin. The documents in the possession of the Geological Society, of which facsimiles are exhibited in the Science Museum, prove that Smith had completed his geological map of the neighbourhood of Bath in 1799 and his first sketch of his geological map of England and Wales in 1801 , while Cuvier and Brongniart did not commence their geological investigation of the Environs of Paris till 1806 , and their map did not appear until i8 ro.

Smith's great geological map of England and Wales was published in I815; Macculloch's geological map of Scotland in 1835 ; and Griffith's geological map of Ireland in 1838 . The first complete geological map of France, that of Elie de Beaumont and Dufrenoy appeared in 1840 .

At the conclusion of the lecture, the President proposed a vote of thanks to the lecturer. He said that he had listened with the greatest interest to the account of the various steps by which the art of geological mapping had been gradually advanced towards perfection. He complimented the Director on the manner in which the exhibits had been collected together and arranged in the galleries, and said he was certain the members had seen a collection of apparatus such as was not to be found in any other place. It had been made, be ventured to think, with extraordinary judgment, and was admirably adapted for the purpose of teaching geology.

A vote of thanks was carried by acclamation, and the members were subsequently most hospitably entertained at tea by Professor Judd. After tea they proceeded to examine the collections in the upper galleries. and eventually separated at the entrance, all agreeing that they had spent a most enjoyable afternoon, and many expressing an intention to revisit the exhibition at an early date. 